\title{
How R\&D Financial Subsidies, Regional R\&D Input, and Intellectual Property Protection Affect the Sustainable Patent Output of SMEs: Evidence from China
}

\author{
Pengyuan $X u^{1, * \mathbb{C}}$, Meiqing Zhang ${ }^{1}$ and Min Gui ${ }^{2}$ \\ 1 School of Economics and Management, Beijing Jiaotong University, Beijing 100044, China; \\ meiqing_zhang@163.com \\ 2 School of Mathematics and Computing Science, Anqing Normal University, Anqing 246133, China; \\ guimin1420@hfrcbc.com \\ * Correspondence: xupengyuan@hotmail.com
}

Received: 6 January 2020; Accepted: 6 February 2020; Published: 7 February 2020

\begin{abstract}
The effects of regional R\&D input (RRDI) and intensity of intellectual property protection (IPP) on the relationship between R\&D financial subsidies (RDFS) and the sustainable patent output of small and medium enterprises (SMEs) is currently a topic of debate. Regional financial support and necessary IPP are vital to the sustainable patent output of SMEs. However, empirical evidence to investigate the role of RRDI and intensity of IPP is insufficient. Therefore, this study aims to reveal the effect of RDFS on the sustainable patent output of SMEs and analyze the role of RRDI and intensity of IPP in the relationship between RDFS and SMEs' sustainable patent output. We collected data from the R\&D activities of SMEs in 30 provinces of China and performed maximum likelihood estimation (MLE) of six equations. The empirical results show that RDFS have a positive impact on the sustainable patent output of SMEs. Besides, RRDI plays a mediating role in the relationship between RDFS and the sustainable patent output of SMEs. Third, the mediating role of regional R\&D personnel input (RRDPI) is more obvious than that of R\&D fund input (RRDFI). Finally, the intensity of IPP significantly moderates the direct effect of RDFS on the sustainable patent output of SMEs and the mediation effect via RRDI.
\end{abstract}

Keywords: R\&D financial subsidies; regional R\&D input; intensity of IPP; sustainable patent out of SMEs

\section{Introduction}

In modern society, SMEs are always vital to the national economy. In China, SMEs account for $99.3 \%$ of the total number of enterprises and $55.6 \%$ of the overall GDP, making a great contribution to China's economic development since the policy of Reform and Opening-up [1]. With the implementation of innovation-driven development strategy, the Chinese government continues to take measures to promote technological innovation of SMEs and increase their patent output to promote economic development. Since the rise of "new economic growth theory" in 1980s, many R\&D economic growth models built by scholars have concluded that $R \& D$ activities are the source of technological progress of enterprises [2,3]. Therefore, with the support of this theory, RDFS have become the main measure to promote SMEs to increase R\&D input, and the main means for the government to stimulate enterprises to increase R\&D investment [4]. The influence mechanism of RDFS and policy effect are generally the research focus. In this context, many scholars have studied the relationship between financial subsidies and regional patent output and the further effects on the patent output of enterprises. Some 
scholars maintain that financial subsidies can produce "incentive effects" on R\&D input and be used as a supplementary means of market mechanism to mobilize the enthusiasm of enterprises in patent research and development [4-6]. However, some scholars argue that the information asymmetry and principal-agent problems between the government, enterprises, universities, and other SMEs will produce "crowding out effect" on RRDI, and have a negative impact on patent output [7-9]. The debate leads to the fact that the mechanism of the effect of financial subsidies on patent output is still uncertain, and becomes a "black box".

With the development of modern economy, in order to improve the enthusiasm of SMEs for continuous technological innovation, countries are also constantly strengthening the intensity of IPP to ensure that SMEs can obtain monopoly profits in the field of applying their innovative technology to realize the sustainable development of patent output [10]. However, too strong protection of property rights will strengthen the technology monopoly of large companies and improve SMEs' technology imitating cost and reducing their innovation power [11]. Therefore, it is still unclear how IPP affects the patent output of SMEs.

What's more, many scholars only pay attention to the mediating role of RRDI in this process, as well as the effects of factors such as R\&D capital, marketization process, and ownership [12-14]. However, the intensity of IPP, as an important institutional guarantee for enterprises to continue patent $R \& D$, has been paid less attention. In addition, the current research on IPP focuses more on the impact of intellectual property on the innovation performance of enterprises [15-17], but does not include the intensity of IPP and the existing government incentive policies into a theoretical framework. Specifically, the empirical research on the mechanism of intellectual property intensity between financial subsidies and the sustainable patent output of SMEs is still insufficient. Therefore, it is necessary to further study the role of IPP intensity and RRDI in the relationship between RDFS and the sustainable patent output of SMEs. To realize the purpose, this paper tries to answer three questions as follows:

(1) What is the relationship between RDFS and the sustainable patent output of SMEs?

(2) What is the role of RRDI in the relationship between RDFS and the sustainable patent output of SMEs?

(3) What role does the intensity of IPP play in the relationship between RDFS and the sustainable patent output of SMEs?

To solve the above problems, this paper comprehensively investigates the interaction mechanism among RDFS, RRDI, IPP intensity and the sustainable patent output of SMEs based on the existing research. Besides, we took data from the SMEs in 30 provinces of China as samples to explore the roles of RRDI and IPP intensity in the relationship between RDFS and the sustainable patent output of SMEs.

The remainder of the article is arranged as follows: In Section 2, we make a literature review and put forward the corresponding assumptions. Section 3 explains the data and measurement of variables. In Section 4, we describe the models and testing methods used to validate the hypotheses. Section 5 reports the test results and corresponding conclusions. Section 6 sets out the theory and policy implications given by the conclusion. The final section gives the limitations and future research directions.

\section{Literature Review and Hypotheses Development}

\subsection{RDFS and the Sustainable Patent Output of SMEs}

RDFS is the main policy adopted by local governments to improve the regional innovation ability [18]. From the perspective of SMEs receiving subsidies, the financial subsidies directly alleviate the financial constraint of SMEs, increase their cash inflow, and improve the ability of SMEs to expand $R \& D$ investment and repay the debt to a certain extent. In that case, SMEs can invest more resources in the R\&D and other innovation departments, and then improve the sustainable patent output [4]. From the government's point of view, the government's financial subsidies to SMEs will convey a positive signal to the market, that is, the patent research and development conducted by SMEs will 
have strong economic and social benefits [19]. This expectation can stimulate external investors and SMES to increase their R\&D investment further, which is more conducive to the improvement of sustainable patent output [1,4]. From the perspective of the whole region, the increase of regional overall financial subsidies, especially for universities and research institutes, can effectively improve the quality of regional human capital and improve the regional innovation environment, which will also be conducive to increasing the R\&D input and improving the patent output of SMEs [20]. Hewitt Dundas et al. [21] found that government financial subsidies can accelerate the R\&D activities of enterprises and promote the development of major new products; Guo et al. [4] also analyzed the relationship between financial subsidies and patent output of enterprises from an empirical perspective, and found that financial subsidies can effectively improve the patent output of enterprises. Based on the above analysis, the following hypothesis is proposed:

Hypothesis 1 (H1). RDFS can significantly improve the sustainable patent output of SMEs.

\subsection{RDFS and RRDI}

There are different opinions on the relationship between RDFS and RRDI. People who hold the view of "incentive effect" think that RDFS can reduce the R\&D cost of SMEs, alleviate their financial constraints, and thus stimulate further increase innovation investment [4-6]. Because of the externality of technological innovation, new technological knowledge will spread uncontrollably, which leads to the fact that SMEs cannot monopolize all the benefits of innovation, thus reducing the investment scale of R\&D activities [22]. In that case, the government's financial subsidies as a supplementary means of market mechanism can reduce the risks of SMEs, improve its anti-risk ability and optimize the allocation of innovation resources to encourage SMEs to increase R\&D investment [23].

The scholars who hold the negative view think that in the innovation system, there are problems of information asymmetry and principal-agent between the government, enterprises, universities, scientific research institutions, which will produce "crowding out effect" on the R\&D activities of SMEs $[7,8,24]$. On the one hand, because the government usually cannot get the complete information of SMEs, it is difficult to choose the subject that should be more subsidized, which makes the financial subsidy resources to not achieve the optimal allocation [7]. On the other hand, because the government is unable to effectively monitor the behavior of enterprises after obtaining subsidies, some enterprises will tend to carry out patent research within the scope of the government support in order to obtain subsidies, and ignore other patent research fields that are more able to produce major technological breakthroughs and have stronger technology spillover [24]. Besides, some enterprises and scientific research institutions will defraud subsidies. The problem of "moral hazard" seriously affects the implementation effect of subsidy policy. The comprehensive effects of these two aspects lead to the fact that the government's financial subsidies have no obvious impact on RRDI. However, according to the "New Economic Growth Theory" [2,3], RDFS is the important origin of R\&D input of enterprises. Thus, the positive effect of RDFS on RRDI is the academic mainstream. Based on this, this study puts forward the following hypothesis:

Hypothesis 2 (H2). RDFS can significantly increase RRDI.

\subsection{RRDI and the Sustainable Patent Output of SMEs}

As for the relationship between RRDI and regional patent output, the academic community has a relatively consistent view. It is acknowledged that the increase of RRDFI and RRDPI will promote the improvement of regional patent output. Clin et al. [6] carried out econometric analysis, and found that there was a positive correlation between the internal expenditure of science and technology activities and patent output of SMEs in Korea. Cowling [25] empirically studied the relationship between R\&D investment and patent output of SMEs in UK, and got the conclusion that there was a positive correlation between R\&D investment and patent output. Hottenrott et al. [26] analyzes the impact and 
effectiveness of targeted public support for R\&D investment at the firm level, and concluded that R\&D financial support and regional $R \& D$ input can have a positive impact on the R\&D output. Moreover, for the reason that RRDFI and RRDPI are the most commonly used indicators to measure regional R\&D input. Therefore, this study puts forward the following assumptions:

Hypothesis 3 (H3). RRDFI can significantly improve the sustainable patent output of SMEs.

Hypothesis 4 (H4). RRDPI can significantly improve the sustainable patent output of SMEs.

\subsection{Mediating Role of RRDI}

The main body of regional innovation is often restricted by various factors such as capital, technology, R\&D personnel investment, competitors, and so on. For example, when SMEs are faced with high capital constraints and technical bottlenecks, their expectation of patent research and development will be reduced, which will actively reduce R\&D capital and personnel input, resulting in a lower level of patent output. At this time, if the government's RDFS to SMEs alleviate the financial constraints and reduce the R\&D cost, that is, the RDFS produce "incentive effect" [5], SMEs will actively increase R\&D input. According to the new economic growth theory [27], the increased $R \& D$ input, as the main input element, can positively affect the patent output of enterprises. If the financial subsidies produce "crowding out effect" [8], then the level of patent output will be reduced correspondingly. Based on the above analysis, RDFS can produce "incentive effect" or "crowding out effect" through R\&D input, which can positively or negatively affect the patent output of enterprises, that is, RRDI plays an mediating role in RDFS and patent output. Therefore, this study proposes the following assumption:

Hypothesis 5 (H5). RRDI plays a significant mediating role between RDFS and the sustainable patent output of SMES.

\subsection{Moderating Role of the Intensity of IPP}

In the process of the influence of RDFS on patent output, the intensity of IPP is a factor that cannot be ignored [16]. Generally, it will moderate the direct effect of RDFS on the sustainable patent output of SMEs from three aspects. First, from the perspective of SMEs, the IPP system can enable SMEs to obtain monopoly position and monopoly profit in the field of applying its innovation technology. Therefore, IPP can provide innovators with returns far beyond the average, and then mobilize innovators to further increase innovation input under the support of government, which is conducive to the accumulation of innovation input [28]. It shows that IPP can strengthen the "incentive effect" of RDFS, thus increasing the sustainable patent output. Second, from the perspective of the government, a thorough IPP system can maintain the enthusiasm of technology investment of enterprises, help patent inventors to obtain monopoly profits and form a virtuous circle. Therefore, the government will be more inclined to give financial support to SMEs that form a virtuous circle to achieve better policy effects [29]. Third, because of the existence of information asymmetry, SMEs are only willing to invest in R\&D activities within the scope of government support in order to obtain more subsidies, while ignoring other patent research fields that may produce major technological breakthroughs and have stronger technology spillover [7]. However, under the condition of a thorough IPP system, in order to monopolize more innovation income, enterprises will increase investment in this kind of patent field to alleviate the "crowding out effect" of RDFS to a certain extent [30]. Therefore, the intensity of IPP can play a positive role in the process of patent output in regions affected by RDFS. Based on the above analysis, this study puts forward the following opposite assumptions:

Hypothesis 6 (H6). The intensity of IPP positively moderate the direct effect of RDFS on the sustainable patent output of SMEs. 
Hypothesis 5 reveals the result that effect of RDFS on the sustainable patent output of SMEs is mediated by RRDI. In the mediation process, IPP intensity also acts as a moderator in four aspects. First, IPP intensity can promote technology market transactions. Only when local enterprises have confidence in the protection of local intellectual property rights, can local enterprises carry out cross regional technology transactions with foreign enterprises. Therefore, a good IPP environment can effectively promote technology transactions between regions, and the benefits brought by cross regional technology transactions can encourage enterprises to further increase the technology input and improve regional patent output level [31]. Second, regions with high intensity of IPP generally have good legislative and judicial environment. A perfect judicial system and enough high-quality judicial personnel can guarantee the effective settlement of regional intellectual property disputes [17], so as to reduce the risk of intellectual property infringement and ensure that SMEs can enjoy the exclusive benefits of innovation and encourage the patent research of SMEs. Third, a good environment for IPP can enhance the public's awareness of respecting and protecting intellectual property, which can effectively reduce the probability of intellectual property infringement in the product sales process and guarantee the further improvement of innovation income of SMEs [32]. Fourth, high intensity of IPP can provide a good environment for SMEs to carry out technical exchanges and cooperation with foreign countries, thus promoting international technology transfer and knowledge spillover [33].

In conclusion, we conclude that the intensity of IPP moderates the mediating effect of RDFS on SMEs' sustainable patent output, as is shown in Figure 1. Therefore, this study generates the following hypothesis:

Hypothesis 7 (H7). The intensity of IPP moderates the strength of the mediating effect between RDFS and SMEs' sustainable patent output via RRDI (such that the mediation effect will be stronger under a high level of IPP intensity than under a low level of IPP intensity).

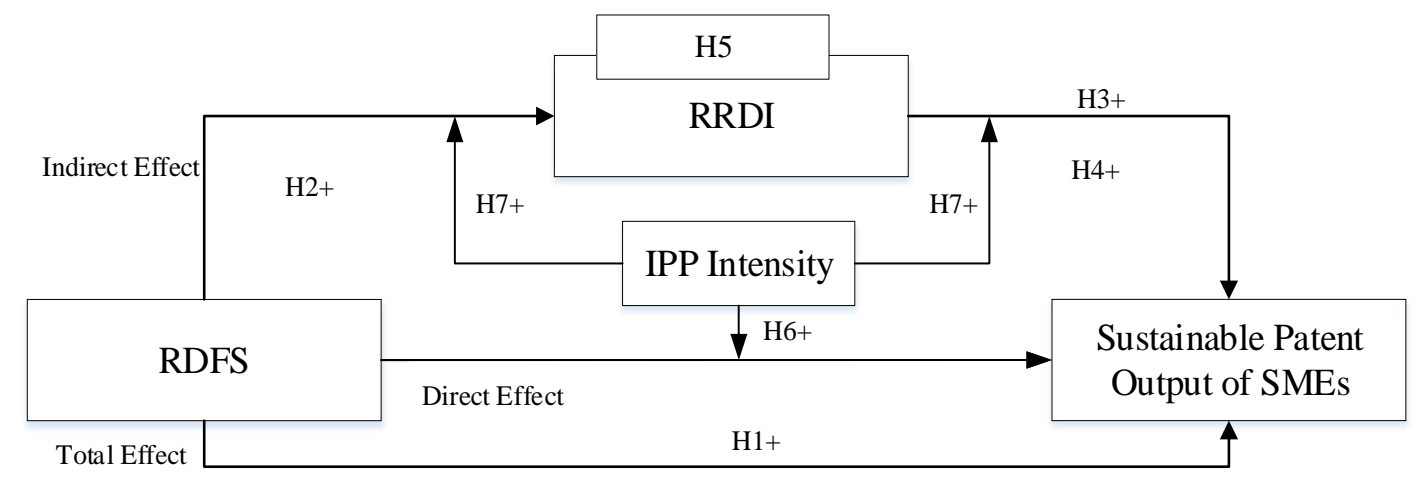

Figure 1. Model of the study.

\section{Methodology}

\subsection{Data}

This study selected the regional level data of R\&D activities of SMEs in 30 provinces of China from 2007 to 2017 to constitute a balance panel $(n=30, t=11)$. Because of the lack of a large number of data, Tibet was not included in the sample. The data of $R \& D$ activities of SMEs in various regions are from the Yearbook of China's Small and Medium-Sized Enterprises from 2007 to 2017, which includes the overall production and operation of SMEs in various regions of China as well as their R\&D activities. The yearbook was compiled by the Small and Medium Enterprises Bureau of the Ministry of Industry and Information Technology. The yearbook data are provided by the competent authorities of SMEs throughout China. The following table reports the profile of the 330 observations in terms of the number of SMEs in each region, the proportion of SMEs' output to the total industrial output, and location (Table 1). 
Table 1. The details of data $(n=330)$.

\begin{tabular}{ccc}
\hline Item & Option or Value & Frequency \\
\hline & $\leq 50$ & $66(20.0 \%)$ \\
Number of SMEs $(10,000)$ & $50-100$ & $88(26.7 \%)$ \\
& $\geq 100$ & $176(53.3 \%)$ \\
\hline \multirow{2}{*}{ SMEs' Output/Total Industrial Output } & $\leq 80$ & $44(13.3 \%)$ \\
& $80-95$ & $88(26.7 \%)$ \\
& $95-100$ & $198(60.0 \%)$ \\
\hline & East & $121(36.7 \%)$ \\
& Middle & $88(26.7 \%)$ \\
& West & $121(36.7 \%)$ \\
\hline
\end{tabular}

\subsection{Measurement of Variables}

Sustainable Patent Output of SMEs: The indicators widely used to measure patent output are generally the number of patent applications, the number of effective patents or the number of authorized patents $[22,34,35]$, among which the number of patent applications represents the number of patents applied by innovative organizations to intellectual property institutions, representing the effort of patent output [14]. The number of effective patents is generally stock, which represents the approved patents by government at the end of the reporting period. However, the number of patents required in this study is traffic and sequential data to denote the sustainable output. The number of authorized patents refers to the number of patents granted by administrators to the applicators during the reporting period, which represents the number of patents actually produced in the region and can directly reflect the patent output [35]. Therefore, this study will choose the number of authorized patents to measure the regional patent output.

RDFS: The government funds included in the R\&D funds of regions was used to denote RDFS, which frequently appear in China's statistical yearbook at the regional level $[8,9,36]$. At the enterprise level, the "government subsidies" disclosed in the annual report of enterprises are treated as an alternative. In view of the research at the regional level, this study used the government funds for SMEs in regional $R \& D$ funds to represent the RDFS obtained by the SMEs in the region.

IPP: The effective measurement method of the intensity of IPP is put forward by Ginarte and Park [34], which is called "GP" index for short. Based on the "GP" index, $\mathrm{Xu}$ and Shan [37] in China increased the indicators to measure the enforcement intensity of IPP from the aspects of economic development level, public awareness of abiding by the law, administrative management level, etc., making them more perfect. However, these factors cannot directly affect the enforcement intensity of intellectual property, but only measure the atmosphere in which the public abides by the law, leading to certain subjectivity of the method. Based on this, Ang et al. [31] proposed a method to measure the level of regional IPP by the turnover of technology trading market, which represents the contract amount of intellectual property transactions between local enterprises and nonlocal enterprises under the condition of property protection. Because only when the intensity of local IPP is high, local enterprises and nonlocal enterprises can carry out cross regional intellectual property. As a result, the turnover of technology trading market in a region can objectively reflect the intensity of IPP in that region. In general, this study uses the turnover of technology trading market to measure the intensity of IPP.

RRDI: According to Lichtenberg and Capasso et al. [38], this study divide RRDI into R\&D fund input and personnel input. The regional R\&D fund input (RRDFI) is measured by the internal R\&D expenditure of each region, including the investment in enterprises, R\&D institutions and colleges and universities. The regional R\&D personnel input (RRDPI) is generally measured by the full-time equivalent of R\&D personnel of each region, similarly including the investment in enterprises, research institutes and universities. In this study, we will use the above two indicators to measure the RRDI.

Control variables: Considering the factors that may affect the regional patent output in the process, we used the level of economic development [14], the level of high-tech industry development [39], 
market capacity [40], and regional openness [41] as control variables. It is generally believed that better economic foundation is more conducive to innovation, so this study used per capita GDP to measure the level of economic development. High-tech industry itself has strong innovative capacity, so it also has strong patent production capacity, this study uses the proportion of the total output value of high-tech industry in the total industrial output value to measure it. Market capacity represents the potential of market patent output, which is measured by the number of industrial enterprises above the scale in each region. High regional openness is conducive to technology exchange and promotes patent output to a certain extent, which is expressed by the proportion of total import and export of each region in the regional GDP of that year.

Table 2 summarizes the variables in terms of their abbreviation, type, operational definition, means, and standard deviation.

Table 2. Type and descriptive statistics of variables.

\begin{tabular}{|c|c|c|c|c|c|}
\hline Variable & Abbreviation & Type & Operational Definition & Mean & $\begin{array}{r}\text { Standard } \\
\text { Deviation }\end{array}$ \\
\hline $\begin{array}{l}\text { Sustainable Patent } \\
\text { Output of SMEs }\end{array}$ & Pat & Dependent variable & $\begin{array}{l}\text { Number of authorized patents } \\
\text { in logarithmic form }\end{array}$ & 5.416 & 1.544 \\
\hline RDFS & Rdfs & Independent variable & $\begin{array}{l}\text { Government funds for SMEs in } \\
\text { logarithmic form }\end{array}$ & 11.854 & 1.199 \\
\hline IPP & Ipp & Moderating variable & $\begin{array}{l}\text { Turnover of technology trading } \\
\text { market in logarithmic form }\end{array}$ & 7.291 & 1.768 \\
\hline RRDFI & Rdf & Mediating variable & $\begin{array}{l}\text { Internal R\&D expenditure of } \\
\text { each region in logarithmic form }\end{array}$ & 8.356 & 1.352 \\
\hline RRDPI & $\operatorname{Rdp}$ & Mediating variable & $\begin{array}{l}\text { Full-time equivalent of R\&D } \\
\text { personnel in logarithmic form }\end{array}$ & 6.742 & 1.177 \\
\hline $\begin{array}{l}\text { Level of Economic } \\
\text { Development }\end{array}$ & Ecle & Control variable & $\begin{array}{l}\text { Per capita GDP in } \\
\text { logarithmic form }\end{array}$ & 10.504 & 0.554 \\
\hline $\begin{array}{l}\text { Level of High-Tech } \\
\text { Industry } \\
\text { Development }\end{array}$ & Hitech & Control variable & $\begin{array}{l}\text { Proportion of the total output of } \\
\text { high-tech industry in the total } \\
\text { industrial output }\end{array}$ & 0.092 & 0.077 \\
\hline Market Capacity & Mc & Control variable & $\begin{array}{l}\text { Number of industrial } \\
\text { enterprises above the scale in } \\
\text { logarithmic form }\end{array}$ & 8.273 & 1.494 \\
\hline Regional Openness & Ro & Control variable & $\begin{array}{l}\text { Proportion of total import and } \\
\text { export in the regional GDP }\end{array}$ & 0.303 & 0.364 \\
\hline
\end{tabular}

\section{Analysis Method}

There are many ways to test the mediation and moderation relationships between variables, such as the Baron and Kenny test [42], the Sobel test [43], the non-parametric bootstrap method after deviation correction [44] and the conditional indirect effect analysis [45,46]. The effectiveness of the latter two methods are stronger than that of the first two [47]. Moreover, the Sobel test is used under the restrict condition that the statistics must be all normal distribution [47]. Therefore, this research used the Baron and Kenny test to investigate the mediation and moderation effects, and carried out robust test using the non-parametric bootstrap method and the conditional indirect effect analysis to ensure the accuracy.

\subsection{Mediation Effect}

In order to test whether regional R\&D input mediates the relationship between RDFS and the sustainable patent output of SMEs, according to Baron and Kenny [42], we can perform OLS regression to test Hypotheses 1 through 5. Regression analysis is considered as one of the most frequently used statistical methods in wide range of fields, which is efficient in analyzing the mediation and moderation relationships among variables. But, because of the "spatial dependence" of RDFS,RRDI and the sustainable patent output of SMEs, we had to include the spatial lagged terms of them into the models. Moreover, the time lags among RDFS,RRDI, and the sustainable patent output of SMEs 
should also be considered. Therefore, we used "spatial panel dynamic model" in the study. Before determining the final form of the models, we need to perform some tests,

First, we need to know if RDFS,RRDI, and the sustainable patent output of SMEs are stationary to decide whether it is necessary to include the difference terms of them. So we carried out the IPS test $(\mathrm{n}=30, \mathrm{~T}=11, \mathrm{n}>\mathrm{T})$ to verify if there is panel unit root. The test is implemented by Stata 15.1 and the results are shown in Tables 3 and 4 .

Table 3. Im-Pesaran-Shin unit-root test for Rdfs and Pat.

\begin{tabular}{cccccccc}
\hline & \multicolumn{2}{c}{ Statistic } & \multicolumn{2}{c}{$p$-Value } & \multicolumn{3}{c}{ Fixed-N Exact Critical Values } \\
\hline & Rdfs & Pat & Rdfs & Pat & $1 \%$ & $5 \%$ & $10 \%$ \\
\hline t-bar & -3.1327 & -2.3781 & & & & & \\
t-tilde-bar & -2.5881 & -2.7391 & & & -1.830 & -1.740 & -1.690 \\
Z-t-tilde-bar & -7.4011 & -7.6752 & $0.00^{* * *}$ & $0.00^{* * *}$ & & & \\
\hline \multicolumn{8}{c}{ Note: ${ }^{* * *} p<0.01}$.
\end{tabular}

Table 4. Im-Pesaran-Shin unit-root test for Rdf and Rdp.

\begin{tabular}{cccccccc}
\hline & \multicolumn{2}{c}{ Statistic } & \multicolumn{2}{c}{$p$-Value } & \multicolumn{2}{c}{ Fixed-N Exact Critical Values } \\
\hline & $\operatorname{Rdf}$ & $\operatorname{Rdp}$ & $\operatorname{Rdf}$ & $\operatorname{Rdp}$ & $1 \%$ & $5 \%$ & $10 \%$ \\
\hline t-bar & -3.2579 & -3.2981 & & & & & \\
t-tilde-bar & -2.6302 & -3.1932 & & & -1.830 & -1.740 & -1.690 \\
Z-t-tilde-bar & -7.7011 & -8.6752 & 0.0000 & 0.0000 & & & \\
\hline
\end{tabular}

According to the testing results, the $p$-value is far smaller than 0.01 . So we can infer that RDFS, RRDI and the sustainable patent output of SMEs are stationary.

After that, we have to decide the time lags among RDFS, RRDI, and the sustainable patent output of SMEs. As for panel data, we used different information criterion (MBIC, MAIC, and MQIC) to select the appropriate time lags, which can be carried out in Stata. For RDFS and the sustainable patent output of SMEs, the program automatically select 1 lag to estimate them. For RDFS and RRDI, the time lag is also 1. Thus, if we just regress the sustainable patent output of SMEs with RDFS, the model is ADL $(1,1)$. However, in view of the spatial terms, the equations should be designed in the form of spatial panel models.

As we all know, there are different spatial panel models, such as SAR model (spatial autoregression model), SAC model (spatial autocorrelation model), SEM model (spatial error model), and SDM model (spatial durbin model). The next work is to determine which one is appropriate. Taking RDFS as independent variable and the sustainable patent output of SMEs as dependent variable, we used Stata 15.1 to carry out LM Lag test to decide whether to apply SAR model, LM Error test for SEM model, and LM SAC test for SAC model (Table 5). The test results are shown as below:

Table 5. LM tests.

\begin{tabular}{cccc}
\hline Hypothesis & Test & Statistics & $p$-Value \\
\hline $\begin{array}{c}\text { Ho: Error has No Spatial AutoCorrelation } \\
\text { Ha: Error has Spatial AutoCorrelation }\end{array}$ & LM Error & 0.0073 & 0.9269 \\
$\begin{array}{c}\text { Ho: Spatial Lagged Dependent Variable has No Spatial AutoCorrelation } \\
\text { Ha: Spatial Lagged Dependent Variable has Spatial AutoCorrelation } \\
\text { Ho: No General Spatial AutoCorrelation } \\
\text { Ha: General Spatial AutoCorrelation }\end{array}$ & LM Lag & 3.7432 & 0.0501 \\
\hline
\end{tabular}

Results from Table 3 show that LM Lag test for spatial lag is more significant than LM Error test for spatial error and the result of LM SAC test is not significant. In consideration of the spatial 
lagged term of independent variable, we used SDM model to investigate the relationships between the two variables.

According to the tests and analyses, Equation (1) is designed as below:

$$
\begin{aligned}
& \text { pat }_{i t}=\alpha_{1}+\sigma_{1} \text { pat }_{i t-1}+\rho_{1} \boldsymbol{w}_{i} \text { pat }_{t}+\beta_{1} r d f s_{i t}+\gamma_{1} r d f_{i t-1}+\theta_{1} w_{i} r d f s_{t}+\sum \varphi \text { control }_{i t}+ \\
& u_{i}+v_{t}+\varepsilon_{i t}
\end{aligned}
$$

Similar tests were performed before the determination of Equations (2) and (3) and they are designed as follows:

$$
\begin{aligned}
& r d_{i t}=\alpha_{2}+\sigma_{2} r d_{i t-1}+\rho_{2} w_{i} r d_{t}+\beta_{2} r d f_{s_{i t}}+\gamma_{2} r d f s_{i t-1}+\theta_{2} \boldsymbol{w}_{i} r d f s_{t}+\sum \varphi \text { control }_{i t}+ \\
& u_{i}+v_{t}+\varepsilon_{i t} \\
& \text { pat }_{i t}=\alpha_{3}+\sigma_{3} \text { pat }_{i t-1}+\rho_{3} \boldsymbol{w}_{i} \text { pat }_{t}+\delta_{1} r d_{i t}+\beta_{3} r d f_{s_{i t}}+\gamma_{3} r d f s_{i t-1}+\theta_{3} \boldsymbol{w}_{i} r d f_{s_{t}}+ \\
& \sum \varphi \text { control } \\
& i t+u_{i}+v_{t}+\varepsilon_{i t}
\end{aligned}
$$

All the equations were estimated using "maximum likelihood estimation" method (MLE) through Stata 15.1. In the regression Equations (1) through (3), pat ${ }_{i t}$ stands for the sustainable patent output of SMEs, $r d f_{s i t}$ for RDFS, $r d_{i t}$ for regional RRDI representing both rdf and rdp, control ${ }_{i t}$ for control variable. The $\alpha_{1}$ through $\alpha_{3}$ are the constant terms. The $u_{i}, v_{t}$, and $\varepsilon_{i t}$ represent the error terms. $u_{i}$ is individual varying disturbing term and $v_{t}$ is the time varying disturbing term. The $\beta_{1}$ through $\beta_{3}$ are the coefficients for $r d f s_{i t}, \gamma_{1}$ through $\gamma_{3}$ for $r d f_{s_{i t-1}}, \theta_{1}$ through $\theta_{3}$ for the spatial lagged term of $r d f s_{i t}$, $\rho_{1}$ through for the spatial lagged term of $p a t_{i t}$ and $r d_{i t}, \sigma_{1}$ and $\sigma_{3}$ for $p a t_{i t-1}, \sigma_{2}$ for $r d_{i t-1}$ and $\delta_{1}$ for $r d_{i t}$. The bold variables are the vector form. The pat $_{t}$ refers to the column vector including all the cross sections at the time of $t$. The $w_{i}$ refers to the weight matrix for the spatial-autoregressive term and other spatial lagged regressors. It is defined as below:

$$
w_{i}=\left\{\begin{array}{l}
1, \text { if the geographical units are contiguous } \\
0, \text { if the geographical units are not contiguous }
\end{array}\right.
$$

The defined contiguity of geographical units is rook contiguity.

Moreover, we took Hausman test for Equation (1) to choose fixed effect or random effect. The result is shown in Table 6.

Table 6. Results of Hausman test.

\begin{tabular}{cccccc}
\hline & B & B & b-B & S.E. \\
\cline { 1 - 3 } & Fe & re & & \\
\hline L.Pat & 0.808 & 0.412 & 0.396 & 0.044 \\
wPat & 0.040 & 0.021 & 0.019 & 0.008 \\
Rdfs & 0.116 & 0.212 & -0.096 & 0.052 \\
L.Rdfs & 0.084 & 1.276 & -1.192 & 0.034 \\
wRdfs & -0.065 & -0.015 & -0.05 & 0.015 \\
Ecle & 1.634 & 1.276 & 0.358 & 0.044 \\
Hitech & 0.523 & 2.617 & -2.094 & 0.317 \\
Mc & -0.011 & 0.086 & -0.097 & 0.007 \\
Ro & -0.336 & -0.435 & 0.099 & 0.120 \\
Cons & -8.812 & -9.520 & 0.708 & 0.511 \\
p & 110.26 & & & \\
Hausman test statistics & $0.000 * * *$ & & & \\
\hline
\end{tabular}

Note: L.Pat means the first-order lag term of Pat, wPat refers to the sptial lag term of Pat, and so on. $b$ is the coefficient obtained from fixed effect regression, B is the coefficient obtained from random effect regression. ${ }^{* * *} p<0.01$. 
The Hausman test statistics is $(b-B)^{\prime}[\operatorname{Var}(b)-\operatorname{Var}(B)](b-B)$. According to the result, the statistics is 110.26 and the p-value is approximately equal to 0 . Thus, we rejected the original hypothesis of random effect and took fixed effect regression.

This study took four steps to examine Hypotheses 1 through 5: in the first and second step, we tested whether the independent variable RDFS had a significant relation with dependent variable pat and mediating variable $r d_{i t}$ to examine Hypothesis 1 and 2. In the third step, we test if the coefficient of mediating variable $\delta_{1}$ is significant to examine Hypothesis 3 and 4 . In the last step, in order to test Hypothesis 5 , we test whether $\beta_{3}$ is smaller than $\beta_{1}$, or insignificant when the mediating variable $r d_{i t}$ is included. If Hypotheses 1 through 5 are accepted, RRDI mediates the relationship between RDFS and the sustainable patent output of SMEs. The current total effect of RDFS on the sustainable patent output of SMEs in time of $\mathrm{t}$ is $\beta_{1}$. The time lagged total effect is $\gamma_{1}$ and the spatial lagged total effect is $\theta_{1}$. The current direct effect in time of $t$ is $\beta_{3}$ and the current indirect effect is $\delta_{1} * \beta_{2}$.

\subsection{Moderation Effect}

In order to test the moderated mediation effect in Hypothesis 6, we must examine if the mediation effect relies on the moderating variable. To distinguish between moderated direct effect and moderated mediation effect, this study designed the following models:

$$
\begin{aligned}
& \text { pat }_{i t}=\alpha_{4}+\sigma_{4} \text { pat }_{i t-1}+\rho_{4} \boldsymbol{w}_{i} p a t_{t}+\beta_{4} r d f_{i t}+\gamma_{4} r d f s_{i t-1}+\theta_{4} w_{i} r d f s_{t}+\mu_{1} i p p_{i t^{*}} \\
& r d f s_{i t}+\sum \varphi \text { control }_{i t}+u_{i}+v_{t}+\varepsilon_{i t} \\
& r d_{i t}=\alpha_{5}+\sigma_{5} r d_{i t-1}+\rho_{5} \boldsymbol{w}_{i} r d_{t}+\beta_{5} r d f s_{i t}+\gamma_{5} r d f_{i t-1}+\theta_{5} \boldsymbol{w}_{i} r d f s_{t}+\mu_{2} i p p_{i t^{*}} \\
& r d f_{i t}+\sum \text { control } i t+u_{i}+v_{t}+\varepsilon_{i t} \\
& \text { pat }_{i t}=\alpha_{6}+\sigma_{6} \text { pat }_{i t-1}+\rho_{6} w_{i} p a t_{t}+\beta_{6} r d f_{s_{i t}}+\gamma_{6} r d f_{i t-1}+\theta_{6} w_{i} r d f s_{t}+\mu_{3} i p p_{i t^{*}} \\
& r d f_{i t}+\delta_{2} r d_{i t}+\tau i p p_{i t} * r d_{i t}+\sum \varphi c o n t r o l_{i t}+u_{i}+v_{t}+\varepsilon_{i t}
\end{aligned}
$$

In the regression Equations (4) through (6), the $\alpha_{4}$ through $\alpha_{6}$ represent the constant term in equations. The ipp it stands for IPP. The $\mu_{1}$ through $\mu_{2}$ are the regression coefficients for the interaction term of $i p p_{i t}$ and $r d f_{s_{i t}}$ and $\tau$ for the interaction term of $i p p_{i t}$ and $r d_{i t}$.

According to the equations, the moderated direct effect can be expressed as $\mu_{3} i p p_{i t}+\beta_{6}$ and the moderated mediation effect is $\left(\tau i p p_{i t}+\delta_{2}\right)\left(\mu_{2} i p p_{i t}+\beta_{5}\right)$. It indicates that the moderated mediation effect is tested under any of the conditions: (1) $\tau \mu_{2} \neq 0$; (2) $\mu_{2} \delta_{2} \neq 0$; (3) $\tau \beta_{5} \neq 0$. If any of the three conditions is satisfied, it indicates that the mediation effect relies on the moderating variable ipp $i$ and the hypothesis 6 is accepted.

\subsection{Robust Test}

For the weak effectiveness of Baron and Kenny test [47], this study applied the non-parametric bootstrap approach to evaluate the mediation effect and the conditional indirect effect analysis to test the moderated mediation effect. We carried out the two tests using the SPSS version PROCESS procedure recommended by Hayes [48].

Both the two tests were applied at 95\% confidence level using the bootstrapping technique to construct 5000 sub-samples [49]. In the conditional indirect effect analysis, we need to calculate the mediation effect at a low and high level of the intensity of IPP.

\section{Results}

\subsection{Mediating Role of Regional RED Input}

As stated above, first, we used the Baron and Kenny test carried out in four steps. The regression results are shown in Table 7. 
Table 7. Results of test of mediation effects.

\begin{tabular}{|c|c|c|c|c|c|}
\hline \multirow{2}{*}{ Variables } & \multirow{2}{*}{$\begin{array}{c}\text { Model (1) } \\
\text { Pat }\end{array}$} & \multicolumn{2}{|r|}{ Model (2) } & \multirow{2}{*}{\multicolumn{2}{|c|}{$\begin{array}{c}\text { Model (3) } \\
\text { Pat }\end{array}$}} \\
\hline & & Rdf & Rdp & & \\
\hline Rdfs & $\begin{array}{l}0.138^{* * *} \\
(0.028)\end{array}$ & $\begin{array}{l}0.435^{* * *} \\
(0.046)\end{array}$ & $\begin{array}{l}0.083 * * \\
(0.035)\end{array}$ & $\begin{array}{l}0.065^{*} \\
(0.039)\end{array}$ & $\begin{array}{l}0.048 \text { ** } \\
(0.020)\end{array}$ \\
\hline Rdf & & & & $\begin{array}{l}0.167 * * * \\
(0.063)\end{array}$ & \\
\hline Rdp & & & & & $\begin{array}{l}1.084^{* * *} \\
(0.378)\end{array}$ \\
\hline L.Pat & $\begin{array}{l}0.808^{* * *} \\
(0.044)\end{array}$ & & & $\begin{array}{l}0.795^{* * *} \\
(0.043)\end{array}$ & $\begin{array}{l}0.808^{* * *} \\
(0.044)\end{array}$ \\
\hline wPat & $\begin{array}{l}0.040 * * * \\
(0.008)\end{array}$ & & & $\begin{array}{l}0.036^{* * *} \\
(0.008)\end{array}$ & $\begin{array}{l}0.040 * * * \\
(0.008)\end{array}$ \\
\hline L.Rdfs & $\begin{array}{l}0.045^{* * *} \\
(0.013)\end{array}$ & $\begin{array}{l}0.038 * * \\
(0.019)\end{array}$ & $\begin{array}{l}0.027 * * \\
(0.012)\end{array}$ & $\begin{array}{c}0.006 \\
(0.012)\end{array}$ & $\begin{array}{c}0.004 \\
(0.011)\end{array}$ \\
\hline wRdfs & $\begin{array}{l}0.065^{* * *} \\
(0.015)\end{array}$ & $\begin{array}{l}0.034^{*} \\
(0.021)\end{array}$ & $\begin{array}{l}0.034^{* * *} \\
(0.009)\end{array}$ & $\begin{array}{l}0.006 \\
(0.017)\end{array}$ & $\begin{array}{l}0.028 * * \\
(0.013)\end{array}$ \\
\hline L.Rdf & & $\begin{array}{l}0.272^{* * * *} \\
(0.036)\end{array}$ & & & \\
\hline wRdf & & $\begin{array}{l}0.047^{* * *} \\
(0.016)\end{array}$ & & & \\
\hline L.Rdp & & & $\begin{array}{l}0.749^{* * *} \\
(0.031)\end{array}$ & & \\
\hline wRdp & & & $\begin{array}{c}0.002 \\
(0.017)\end{array}$ & & \\
\hline Ecle & $\begin{array}{c}-0.107 * * * \\
(0.062)\end{array}$ & $\begin{array}{c}0.214^{* * *} \\
(0.038)\end{array}$ & $\begin{array}{l}0.317^{* * *} \\
(0.044)\end{array}$ & $\begin{array}{c}-0.273 * * * \\
(0.077)\end{array}$ & $\begin{array}{l}0.138^{* * *} \\
(0.028)\end{array}$ \\
\hline Hitech & $\begin{array}{l}1.467^{* * *} \\
(0.356)\end{array}$ & $\begin{array}{l}0.367^{* * *} \\
(0.074)\end{array}$ & $\begin{array}{l}0.566 * * \\
(0.309)\end{array}$ & $\begin{array}{l}1.054^{* * *} \\
(0.504)\end{array}$ & $\begin{array}{l}0.508^{* * *} \\
(0.015)\end{array}$ \\
\hline Mc & $\begin{array}{l}0.298^{* * *} \\
(0.024)\end{array}$ & $\begin{array}{l}0.418^{* * *} \\
(0.217)\end{array}$ & $\begin{array}{l}0.368^{* * *} \\
(0.026)\end{array}$ & $\begin{array}{l}0.348^{* * *} \\
(0.042)\end{array}$ & $\begin{array}{l}-0.054^{* * * *} \\
(0.037)\end{array}$ \\
\hline Ro & $\begin{array}{l}0.341^{* * *} \\
(0.104)\end{array}$ & $\begin{array}{l}-0.044 \\
(0.100)\end{array}$ & $\begin{array}{c}0.042 \\
(0.136)\end{array}$ & $\begin{array}{l}0.535^{* * *} \\
(0.101)\end{array}$ & $\begin{array}{l}0.204^{* * *} \\
(0.012)\end{array}$ \\
\hline Log-likelihood & 140.45 & 139.68 & 140.32 & 123.11 & 135.35 \\
\hline Adusted $\mathrm{R}^{2}$ & $87.05 \%$ & $90.20 \%$ & $75.46 \%$ & $89.15 \%$ & $88.16 \%$ \\
\hline Total Effect & & 0.138 & & \\
\hline Direct Effect (Rdf as Mediator) & & & Direct Effect (Rdp as Mediator) & \multicolumn{2}{|c|}{0.048} \\
\hline Mediation & \multicolumn{2}{|c|}{0.065} & Mediation & \\
\hline $\begin{array}{c}\text { Effect } \\
\text { (Rdf as Mediator) }\end{array}$ & \multicolumn{2}{|c|}{0.073} & $\begin{array}{c}\text { Effect } \\
\text { (Rdp as Mediator) }\end{array}$ & \multicolumn{2}{|c|}{0.090} \\
\hline
\end{tabular}

Note: L.Pat means the first order lag term of Pat, wPat refers to the spatial lag term of Pat, and so on, ${ }^{* * *} p<0.011^{* *}$ $p<0.05, * p<0.1$ with Robust standard errors in parentheses.

In the first step, at the significance level of $1 \%$, RDFS positively influenced the sustainable patent output of SMEs $\left(\beta_{1}=0.138\right.$, $\mathrm{t}$-value $\left.=0.028\right)$, so hypothesis $\mathrm{H} 1$ is accepted. In the second step, the coefficient $\beta_{2}$ is significantly positive at the significance level of $1 \%$, which indicates that RDFS had positive impact on regional R\&D input, therefore Hypothesis $\mathrm{H} 2$ is accepted. In the third step, regional R\&D fund and personnel input had significant positive effect on the sustainable patent output of SMEs $\left(\delta_{1}=0.167\right.$, t-value $=0.063 ; \delta=1.084$, $\mathrm{t}$-value $\left.=0.378\right)$ at $1 \%$ significance level, hence Hypothesis $\mathrm{H} 3$ and $\mathrm{H} 4$ were supported. In the last step, it is shown that $\beta_{3}$ is significant and smaller than $\beta_{1}$, which revealed that the effect of financial subsidies on the sustainable patent output of SMEs was partially mediated by regional R\&D fund and personnel input, thus Hypothesis 5 is accepted. Moreover, the results also indicated that when regional R\&D fund input was used as the mediating variable, the mediation effect accounts for $52.9 \%(0.073 / 0.138)$ of the total effect, and as for regional R\&D personnel input, the mediation effect accounts for $65.2 \%(0.090 / 0.138)$. It revealed that compared with RRDFI, RRDPI played a more significant mediating role in the relationship between RDFS and the sustainable patent output of SMEs. 


\subsection{Moderating Role of IPP Intensity}

According to the Equations (4) through (6), the moderated direct effect can be expressed as $\mu_{3} i p p_{i t}+\beta_{6}$, and the moderated mediation effect is $\left(\tau i p p_{i t}+\delta_{2}\right)\left(\mu_{2} i p p_{i t}+\beta_{5}\right)$. As is shown in Table 8 , the IPP positively moderated the direct effect of RDFS on the sustainable patent output of SMEs at the significance level of $5 \%\left(\mu_{3}=0.012, \mathrm{t}\right.$-value $=0.006$, rdf as mediator; $\mu_{3}=0.005$, $\mathrm{t}$-value $=0.003$, rdp as mediator). So hypothesis H6 was accepted.

Table 8. Results of test of moderation effects.

\begin{tabular}{|c|c|c|c|c|c|}
\hline \multirow{2}{*}{ Variables } & \multirow{2}{*}{$\frac{\text { Model (4) }}{\text { Pat }}$} & \multicolumn{2}{|c|}{ Model (5) } & \multicolumn{2}{|c|}{ Model (6) } \\
\hline & & Rdf & Rdp & \multicolumn{2}{|c|}{ Pat } \\
\hline Rdfs & $\begin{array}{l}0.124^{* * *} \\
(0.037)\end{array}$ & $\begin{array}{l}0.433^{* * *} \\
(0.046)\end{array}$ & $\begin{array}{l}0.048^{*} \\
(0.022)\end{array}$ & $\begin{array}{l}0.037^{* *} \\
(0.014)\end{array}$ & $\begin{array}{c}0.111^{* * *} \\
(0.040)\end{array}$ \\
\hline Rdf & & & & $\begin{array}{l}0.145^{* *} \\
(0.063)\end{array}$ & \\
\hline $\operatorname{Rdp}$ & & & & & $\begin{array}{l}0.871^{* * *} \\
(0.284)\end{array}$ \\
\hline L.Pat & $\begin{array}{l}0.800 * * * \\
(0.044)\end{array}$ & & & $\begin{array}{l}0.784^{* * *} \\
(0.043)\end{array}$ & $\begin{array}{l}0.794^{* * *} \\
(0.045)\end{array}$ \\
\hline wPat & $\begin{array}{l}0.040^{* * * *} \\
(0.008)\end{array}$ & & & $\begin{array}{c}0.036^{* * * *} \\
(0.017)\end{array}$ & $\begin{array}{l}0.041^{* * *} \\
(0.008)\end{array}$ \\
\hline L.Rdfs & $\begin{array}{l}0.042^{* * *} \\
(0.015)\end{array}$ & $\begin{array}{l}0.033 * \\
(0.020)\end{array}$ & $\begin{array}{l}0.022 * * \\
(0.010)\end{array}$ & $\begin{array}{c}0.037^{* * *} \\
(0.012)\end{array}$ & $\begin{array}{c}0.023 \\
(0.019)\end{array}$ \\
\hline wRdfs & $\begin{array}{l}0.065^{* * *} \\
(0.015)\end{array}$ & $\begin{array}{l}0.035^{*} \\
(0.021)\end{array}$ & $\begin{array}{l}0.008^{* *} \\
(0.004)\end{array}$ & $\begin{array}{c}0.060^{* * * *} \\
(0.017)\end{array}$ & $\begin{array}{c}0.058 \\
(0.044)\end{array}$ \\
\hline L.Rdf & & $\begin{array}{l}0.269^{* * * *} \\
(0.036)\end{array}$ & & & \\
\hline wRdf & & $\begin{array}{c}0.049^{* * *} \\
(0.016)\end{array}$ & & & \\
\hline L.Rdp & & & $\begin{array}{l}0.761^{* * *} \\
(0.033)\end{array}$ & & \\
\hline wRdp & & & $\begin{array}{l}0.030 * * * \\
(0.010)\end{array}$ & & \\
\hline Rdfs*Ipp & $\begin{array}{l}0.018^{* * *} \\
(0.006)\end{array}$ & $\begin{array}{l}0.008^{* * *} \\
(0.003)\end{array}$ & $\begin{array}{l}0.005^{* *} \\
(0.002)\end{array}$ & $\begin{array}{l}0.012 * * \\
(0.006)\end{array}$ & $\begin{array}{l}0.005^{*} \\
(0.003)\end{array}$ \\
\hline Rdf*Ipp & & & & $\begin{array}{l}0.013 * \\
(0.008)\end{array}$ & \\
\hline Rdp*Ipp & & & & & $\begin{array}{l}0.015^{* *} \\
(0.006)\end{array}$ \\
\hline Ecle & $\begin{array}{l}-0.131^{* *} \\
(0.052)\end{array}$ & $\begin{array}{l}0.478^{* * *} \\
(0.047)\end{array}$ & $\begin{array}{l}0.147^{* * * *} \\
(0.034)\end{array}$ & $\begin{array}{l}-0.146^{* * *} \\
(0.023)\end{array}$ & $\begin{array}{l}-0.234^{* * *} \\
(0.035)\end{array}$ \\
\hline Hitech & $\begin{array}{l}1.233^{* * *} \\
(0.578)\end{array}$ & $\begin{array}{l}0.893^{* *} \\
(0.462)\end{array}$ & $\begin{array}{l}0.875^{* * * *} \\
(0.225)\end{array}$ & $\begin{array}{l}1.458^{* * *} \\
(0.534)\end{array}$ & $\begin{array}{l}1.442^{* * *} \\
(0.322)\end{array}$ \\
\hline Mc & $\begin{array}{l}0.793 * * * \\
(0.033)\end{array}$ & $\begin{array}{l}0.849^{* * * *} \\
(0.031)\end{array}$ & $\begin{array}{l}0.645^{* * *} \\
(0.031)\end{array}$ & $\begin{array}{c}0.596^{* * *} \\
(0.042)\end{array}$ & $\begin{array}{l}0.448^{* * *} \\
(0.035)\end{array}$ \\
\hline Ro & $\begin{array}{l}0.468^{* * *} \\
(0.137)\end{array}$ & $\begin{array}{l}-0.156^{*} \\
(0.078)\end{array}$ & $\begin{array}{l}-0.065 \\
(0.072)\end{array}$ & $\begin{array}{c}0.524^{* * *} \\
(0.112)\end{array}$ & $\begin{array}{c}0.433^{* * *} \\
(0.115)\end{array}$ \\
\hline Log-likelihood & 142.93 & 147.63 & 145.03 & 134.35 & 193.98 \\
\hline Adusted $\mathrm{R}^{2}$ & $89.83 \%$ & $89.88 \%$ & $94.28 \%$ & $97.44 \%$ & $94.33 \%$ \\
\hline Total Effect & & & $0.124+0.018^{*} \mathrm{ipp}$ & & \\
\hline $\begin{array}{l}\text { Direct Effect (Rdf } \\
\text { as Mediator) }\end{array}$ & 0.037 & ipp & $\begin{array}{l}\text { Direct Effect (Rdp } \\
\text { as Mediator) }\end{array}$ & 0.111 & ipp \\
\hline $\begin{array}{c}\text { Mediation } \\
\text { Effect } \\
\text { (Rdf as Mediator) }\end{array}$ & $\left(0.433+0.008^{*}\right.$ & $15+0.013^{*}$ ipp) & $\begin{array}{c}\text { Mediation } \\
\text { Effect } \\
\text { (Rdp as Mediator) }\end{array}$ & $\left(0.048+0.005^{*} \mathrm{i}\right.$ & $\left.71+0.015^{*} \mathrm{ipp}\right)$ \\
\hline
\end{tabular}

Note: ${ }^{* * *} p<0.01,{ }^{* *} p<0.05,{ }^{*} p<0.1$ with Robust standard errors in parentheses.

In order to test the moderated mediation effect. We need to verify whether $\left(\tau i p p_{i t}+\delta_{2}\right)\left(\mu_{2} i p p_{i t}+\beta_{5}\right)$ is relied on $i p p_{i t}$, that is to say, we need to know if the three conditions $\left(\tau \mu_{2} \neq 0, \mu_{2} \delta_{2} \neq 0, \tau \beta_{5} \neq 0\right)$ are satisfied. In Equation (5) the interaction term of $i p p_{i t}$ and $r d s u_{i t}$ had positive impact on $r d_{i t}\left(\mu_{2}=0.008\right.$, $\mathrm{t}$-value $=0.003$, rdf as mediator; $\mu_{2}=0.005$, $\mathrm{t}$-value $=0.002$, rdp as mediator). RRDI has positive effect on the sustainable patent output of SMEs in Equation (6) $\left(\delta_{2}=0.145\right.$. $\mathrm{t}$-vaue $=0.063$, rdf as mediator; 
$\delta_{2}=0.871$. $\mathrm{t}$-value $=0.284$, rdp as mediator). In Equation (5), RDFS positively influenced the regional $\mathrm{R} \& \mathrm{D}$ input $\left(\beta_{5}=0.433, \mathrm{t}\right.$-value $=0.046, \mathrm{rdf}$ as mediator; $\beta_{5}=0.048, \mathrm{t}$-value $=0.022, \mathrm{rdp}$ as mediator). Apparently, the condition $\mu_{2} \delta_{2} \neq 0$ is satisfied and the Hypothesis H7 is tested.

\subsection{Robust Test}

To ensure the accuracy of our tests, this study carried out two robust tests of the mediation and moderation effect.

First, we took the non-parametric bootstrap approach to evaluate the mediation effect of regional R\&D input, as is shown in Table 9. It indicates that the result of non-parametric bootstrap approach is roughly the same as that of Table 7 . When $R \& D$ fund input is the mediating variable, the direct effect of RDFS on the sustainable patent output of SMEs is 0.065 (confidence interval is 0.043 to 0.129 ), and the mediation effect is 0.073 accounting for $52.9 \%$ of the total. However, when RRDPI was included as a mediator, the mediation effect increased obviously to $65.2 \%$.

Table 9. Non-parametric bootstrap test of the mediation effects.

\begin{tabular}{|c|c|c|c|c|c|c|c|}
\hline \multirow{3}{*}{ Variable } & \multirow{3}{*}{$\begin{array}{c}\text { Model (1) } \\
\text { Pat }\end{array}$} & \multicolumn{2}{|c|}{ Model (2) } & \multirow{2}{*}{\multicolumn{4}{|c|}{$\begin{array}{c}\text { Model (3) } \\
\text { Pat }\end{array}$}} \\
\hline & & \multirow[t]{2}{*}{ Rdf } & \multirow[t]{2}{*}{ Rdp } & & & & \\
\hline & & & & Coefficient & CI & Coefficient & CI \\
\hline Rdfs & $\begin{array}{c}0.138^{* * *} \\
(0.028)\end{array}$ & $\begin{array}{c}0.435^{* * *} \\
(0.046)\end{array}$ & $\begin{array}{l}0.083 * * \\
(0.035)\end{array}$ & $\begin{array}{l}0.065^{*} \\
(0.039)\end{array}$ & & $\begin{array}{l}0.048^{* *} \\
(0.020)\end{array}$ & \\
\hline Rdf & & & & $\begin{array}{c}0.167^{* * *} \\
(0.063)\end{array}$ & & & \\
\hline $\mathrm{Rdp}$ & & & & & & $\begin{array}{c}1.084^{* * *} \\
(0.378)\end{array}$ & \\
\hline Direct Effect & & & & 0.065 & $(0.043,0.129)$ & 0.048 & $(0.022,0.113)$ \\
\hline Mediation Effect & & & & 0.073 & $(0.054,0.151)$ & 0.090 & $(0.066,0.186)$ \\
\hline Total Effect & & & & 0.138 & $(0.107,0.235)$ & 0.138 & $(0.107,0.235)$ \\
\hline Proportion of Mediating Effect & & & & $52.9 \%$ & & $65.2 \%$ & \\
\hline
\end{tabular}

Note: ${ }^{* * *} p<0.01,{ }^{* *} p<0.05,{ }^{*} p<0.1$ with robust standard errors in parentheses.

Second, this study applied conditional indirect effect analysis to test Hypothesis 6 and 7. When RRDFI is the mediating variable, results from Table 10 indicated that the RDFS' direct effects with high level of IPP were significantly different from that with low level of IPP (difference of direct effect $=$ $0.042, \mathrm{SE}=0.017, p<0.01$ ). Moreover, the difference between the mediation effects under high and low level of IPP was also significant (difference of mediation effect $=0.021, \mathrm{SE}=0.012, p<0.1$ ). The results were consistent when RRDPI is the mediating variable, and testing results were shown in Table 11. Therefore, the results of Hypothesis 6 and 7 were supported by the condition.

Table 10. Results of conditional indirect effect analysis (RRDFI as mediating variable).

\begin{tabular}{|c|c|c|c|c|c|c|c|c|}
\hline \multirow{3}{*}{$\begin{array}{l}\text { Moderating } \\
\text { Variable }\end{array}$} & \multirow{3}{*}{ Level } & \multicolumn{6}{|c|}{ Effects } & \multirow{3}{*}{$\begin{array}{c}\text { Proportion of } \\
\text { Mediating } \\
\text { Effect }\end{array}$} \\
\hline & & \multicolumn{6}{|c|}{ RDFS $\rightarrow$ RRDFI $\rightarrow$ Pat } & \\
\hline & & \multicolumn{3}{|c|}{ Direct Effect } & \multicolumn{3}{|c|}{ Mediation Effect } & \\
\hline \multirow{3}{*}{$\begin{array}{l}\text { Intensity of } \\
\text { IPP }\end{array}$} & $\begin{array}{c}\text { Low } \\
\text { ipp }=11.423\end{array}$ & $\begin{array}{c}0.174^{* * *} \\
(0.018)\end{array}$ & 0.139 & 0.209 & $\begin{array}{c}0.156^{* * *} \\
(0.011)\end{array}$ & 0.127 & 0.248 & $47.27 \%$ \\
\hline & $\begin{array}{c}\text { High } \\
\text { ipp }=14.959\end{array}$ & $\begin{array}{c}0.216^{* * *} \\
(0.017)\end{array}$ & 0.183 & 0.249 & $\begin{array}{c}0.177^{* * *} \\
(0.016)\end{array}$ & 0.159 & 0.392 & $45.04 \%$ \\
\hline & $\begin{array}{l}\text { High-Low } \\
\text { ipp = } 3.536\end{array}$ & $\begin{array}{c}0.042^{* * *} \\
(0.017)\end{array}$ & 0.035 & 0.062 & $\begin{array}{l}0.021^{*} \\
(0.012)\end{array}$ & 0.012 & 0.034 & $2.23 \%$ \\
\hline
\end{tabular}

Note: ${ }^{* * *} p<0.01,{ }^{*} p<0.1$ with robust standard errors in parentheses. 
Table 11. Results of conditional indirect effect analysis (RRDPI as mediating variable).

\begin{tabular}{|c|c|c|c|c|c|c|c|c|}
\hline \multirow{4}{*}{$\begin{array}{l}\text { Moderating } \\
\text { Variable }\end{array}$} & \multirow{4}{*}{ Level } & \multicolumn{6}{|c|}{ Effects } & \multirow{4}{*}{$\begin{array}{l}\text { Proportion of } \\
\text { Mediating } \\
\text { Effect }\end{array}$} \\
\hline & & \multicolumn{6}{|c|}{ RDFS $\rightarrow$ RRDPI $\rightarrow$ Pat } & \\
\hline & & \multicolumn{3}{|c|}{ Direct Effect } & \multicolumn{3}{|c|}{ Mediation Effect } & \\
\hline & & Coefficient & Lower Limit & Upper Limit & Coefficient & Lower Limit & Upper Limit & \\
\hline \multirow{3}{*}{$\begin{array}{l}\text { Intensity of } \\
\text { IPP }\end{array}$} & $\begin{array}{c}\text { Low } \\
\text { ipp }=11.423\end{array}$ & $\begin{array}{c}0.168^{* * *} \\
(0.010)\end{array}$ & 0.149 & 0.193 & $\begin{array}{c}0.162 * * * \\
(0.022)\end{array}$ & 0.166 & 0.425 & $49.09 \%$ \\
\hline & $\begin{array}{c}\text { High } \\
\text { ipp }=14.959\end{array}$ & $\begin{array}{c}0.186^{* * *} \\
(0.011)\end{array}$ & 0.160 & 0.202 & $\begin{array}{c}0.207 * * * \\
(0.023)\end{array}$ & 0.187 & 0.493 & $52.67 \%$ \\
\hline & $\begin{array}{l}\text { High-Low } \\
\text { ipp }=3.536\end{array}$ & $\begin{array}{l}0.018^{* *} \\
(0.010)\end{array}$ & 0.001 & 0.037 & $\begin{array}{l}0.045^{* *} \\
(0.022)\end{array}$ & 0.009 & 0.083 & $3.58 \%$ \\
\hline
\end{tabular}

Note: ${ }^{* * *} p<0.01{ }^{* *} p<0.05$, with robust standard errors in parentheses.

\section{Discussion}

\subsection{Discussion of the Findings}

Based on the MLE of "spatial panel dynamic model" and robust test by using the data of SMEs from 30 provinces in China, this paper presents four findings.

First, RDFS positively and significantly affects RRDI and the sustainable patent output of SMEs. The positive impact of RDFS on RRDI is consistent with the results of Cin et al. [6], who found significant evidence for positive effects of the R\&D subsidies on the R\&D expenditure of Korean manufacturing SMEs. Dirk et al. [36] and Görg et al. [8] also found that the crowding-out effects with regard to public funding did not exist for specific firm types, which is also congruent with our findings. We also found the positive association between RDFS and the sustainable patent output of SMEs, which is also consistent with Cin et al. [6]. The result is similar with Alecke et al. [5] who found that subsidized firms indeed show a higher level of $R \& D$ intensity and a higher probability for patent application compared to non-subsidized firms.

Second, RRDI acts as a mediator in the relationship between RDFS and the sustainable patent output of SMEs. The mediating role of RRDI in the relationship between RDFS and patent output has not received enough attention. However, studies carried out by Cowling [25] and Hottenrott et al. [26] show that RDFS positively influence R\&D investment, which can significantly increase the $R \& D$ output of SMEs. In this context, we put forward the hypothesis 6 and the testing results proved that RRDI indeed mediates the relationship between RDFS and the sustainable patent output of SMEs, which is similar to Zhang et al. [50], who suggested that R\&D investment mediated the relationship between corporate governance and firm performance.

Third, the mediating role of RRDPI is more significant than that of RRDFI. The interaction effect of R\&D fund input and human capital investment has been investigated by Han [51], Yang et al. [39] and Lin et al. [52]. However, little research has been carried out on the comparison of the two types of investment in the process of R\&D output. Therefore, we attempted to fill the gap by probe into the difference between the two types of investment in the relationship between RDFS and the sustainable patent output of SMEs.

Fourth, the intensity of IPP significantly moderate the direct effect of RDFS on the sustainable patent output of SMEs and the mediation effect via RRDI, which means that the mediation effect will be stronger under a high intensity of IPP than a low intensity of IPP. The effects of IPP on the industrial development [28], product innovation [29], and patent output [14] have been tested by many scholars. However, the moderating effect of IPP intensity has not drawn sufficient attention. In the context, the Hypothesis 6 and 7 proposed the validated moderating role of IPP intensity between RDFS and the sustainable patent output of SMEs, which is similar to Barbu and Militaru [30] who found that intellectual property rights have moderating effect on the relationship between innovation and company innovation performance in manufacturing sector. 


\subsection{Theoretical Implications}

This study has described the relationships among RDFS, RRDI, intensity of IPP and the sustainable patent output of SMEs. RDFS promotes the sustainable patent output of SMEs through its effects on RRDI. Moreover, the direct and mediation effect is moderated by the intensity of IPP. This indicates the importance of using multiple theories and concepts to explain how financial subsidies affect the innovation output of enterprises. Examining the contribution of RDFS to SMEs' sustainable patent output in terms of multiple concepts and perspectives is vital as it expands our understanding of financial subsidies.

The research on the mediating role of RRDI and the moderating role of IPP intensity filled the gap that the mechanism of the effect of financial subsidies on patent output is still controversial. Besides, the difference between the effect of human capital input and fund input on patent output was investigated in this paper, which has attracted little attentions from scholars. Finally, this paper emphasized the importance of IPP intensity and included it into a theoretical framework with RDFS and RRDI, which provided a new perspective to explore the impact of intellectual property rights on innovation.

The application of different testing methods used in this paper also enriched related empirical literature. Previous research usually carried out single method to test mediation and moderation effects, leaving suspects of the accuracy of testing results. We applied methods with different efficiency to test the hypotheses. The consistent testing results verified the validity of Baron and Kenny test, non-parametric bootstrap, method and the conditional indirect effect analysis.

\subsection{Managerial Implications}

As expected, the findings from this research presents useful managerial implications as follows: First, the empirical study shows that RDFS have a strong role in promoting regional patent output. The government should continue to increase RDFS, reduce the principal-agent and moral hazard between the government and SMEs to reduce the "crowding out effect." The government should increase its support for R\&D personnel input in the region. From the empirical research results, R\&D personnel investment in the region plays a stronger mediating role in the relationship between financial subsidies and patent output. Therefore, the government should encourage SMEs to increase the intensity of RRDDPI in the region.

Second, policy makers should further strengthen the guidance and incentive role of IPP on RRDI. From the empirical results of this research, we can see that the intensity has a significant positive regulatory role in increasing RRDI. Therefore, it is necessary to recognize the fact that the current level of IPP in China is still low and government need to strengthen the protection of intellectual property rights. Besides, relevant departments should actively safeguard the patent rights enjoyed by SMEs, so as to prevent their patent technology from being infringed and protect SMEs to obtain reasonable innovation income.

Third, it is necessary to improve the system construction of property rights protection to provide a good system and legal environment for SMEs. IPP can improve patent output in promoting technology market transactions, building a good judicial environment, strengthening the public awareness of property protection and promoting the import and export of patented products. To maintain the positive moderating effect of IPP intensity on SMEs' patent output after R\&D input, efforts must be made in the judicial protection of intellectual property, public awareness of abiding by the law and the construction of technology trading market.

\subsection{Limitations and Future Research Directions}

Although this study contributes to the literature on the financial subsidies and sustainable patent output of SMEs, it has some limitations. First, the data used in this research is regional level. Future studies can conduct similar research with firm-level data of SMEs. Moreover, the main body of regional 
innovation generally includes enterprises, colleges and universities, scientific research institutions, etc., which have different budget soft constraints and anti-risk capabilities. Therefore, the impact mechanism of RDFS on their patent output is not the same for different research subject. At present, the research focus is mainly on enterprises and less attention is paid to other types of institutions. Therefore, further research should be carried out on the impact mechanism of IPP and R\&D input of different institutions. Third, there may be other mediation variables in the relationship between RDFS and the sustainable patent output of SMEs, but they are not covered in the article for the research scope. Thus, it can be investigated in the future. Lastly, the government's stimulus policies for regional patent output include not only financial subsidies, but also tax credits and other policies. Policy combinations are becoming more and more popular in many countries. In that case, whether the impact of policy combinations have effects on regional patent output and is regulated by the intensity of IPP is also worthy of further study.

Author Contributions: P.X. and M.Z. conceptualized the idea of the study design, performed statistical analysis and wrote the manuscript. M.G. helped in the data collection and provided her intellectual insights. All authors have read and agreed to the published version of the manuscript.

Funding: This work was supported by National Natural Science Foundation of China (grant No.71874011).

Conflicts of Interest: The authors declare no conflict of interest.

\section{References}

1. Zhu, Y.; Wittmann, X.; Peng, M.W. Institution-based barriers to innovation in SMEs in China. Asia Pac. J. Manag. 2012, 29, 1131-1142. [CrossRef]

2. Romer, P.M. Endogenous technological change. J. Polit. Econ. 1990, 98, 71-102. [CrossRef]

3. Griliches, Z. R \& D and the productivity slowdown. Am. Econ. Rev. 1980, 70, 343-348.

4. Guo, D.; Guo, Y.; Jiang, K. Government-subsidized R\&D and firm innovation: Evidence from China. Res. Policy 2016, 45, 1129-1144. [CrossRef]

5. Alecke, B.; Mitze, T.; Reinkowski, J.; Untiedt, G. Does Firm Size make a Difference? Analysing the Effectiveness of R\&D Subsidies in East Germany. Ger. Econ. Rev. 2011, 13, 174-195. [CrossRef]

6. Cin, B.C.; Kim, Y.J.; Vonortas, N.S. The Impact of Public R\&D Subsidy on Small Firm Productivity: Evidence from Korean SMEs. Small Bus. Econ. 2017, 48, 345-360. [CrossRef]

7. Lach, S. Do R\&D Subsidies Stimulate or Displace Private R\&D? Evidence from Israel. J. Ind. Econ. 2010, 50, 369-390. [CrossRef]

8. Görg, H.; Strobl, E. The Effect of R\&D Subsidies on Private R\&D. Economica 2007, 74, 215-234. [CrossRef]

9. Boeing, P. The allocation and effectiveness of China's R\&D subsidies-Evidence from listed firms. Res. Policy 2016, 45, 1774-1789. [CrossRef]

10. Kanwar, S.; Sperlich, S. Innovation, productivity and intellectual property reform in an emerging market economy: Evidence from India. Empir. Econ. 2019. [CrossRef]

11. Brüggemann, J.; Crosetto, P.; Meub, L.; Bizer, K. Intellectual property rights hinder sequential innovation. Experimental evidence. Res. Policy 2016, 45, 2054-2068. [CrossRef]

12. Hu, A.G. Ownership, Government R\&D, Private R\&D, and Productivity in Chinese Industry. J. Comp. Econ. 2001, 29, 136-157. [CrossRef]

13. Vancauteren, $M$. The effects of human capital, $R \& D$ and firm's innovation on patents: A panel study on Dutch food firms. J. Technol. Transf. 2018, 43, 901-922. [CrossRef]

14. Yang, C.H.; Kuo, C.C.; Ramstetter, E.D. Intellectual Property Rights and Patenting in China's High-technology Industries: Does Ownership Matter? China World Econ. 2011, 19, 102-122. [CrossRef]

15. Aghion, P.; Howitt, P.; Prantl, S. Patent rights, product market reforms, and innovation. J. Econ. Growth 2015, 20, 223-262. [CrossRef]

16. Lai, L.C. International intellectual property rights protection and the rate of product innovation. J. Dev. Econ. 1998, 55, 133-153. [CrossRef]

17. Sweet, C.M.; Eterovic Maggio, D.S. Do Stronger Intellectual Property Rights Increase Innovation? World Dev. 2015, 66, 665-677. [CrossRef] 
18. Neicu, D.; Teirlinck, P.; Kelchtermans, S. Dipping in the policy mix: Do R\&D subsidies foster behavioral additionality effects of R\&D tax credits? Econ. Innov. New Technol. 2014, 25, 218-239. [CrossRef]

19. Dirk, C.; Julie, D. R\&D policies for young SMEs: Input and output effects. Small Bus. Econ. 2015, 3, 465-485. [CrossRef]

20. Klemetsen, M.E.; Bye, B.; Raknerud, A. Can Direct Regulations Spur Innovations in Environmental Technologies? A Study on Firm-Level Patenting. Scand. J. Econ. 2018, 120, 338-371. [CrossRef]

21. Hewitt-Dundas, N.; Roper, S. Output Additionality of Public Support for Innovation: Evidence for Irish Manufacturing Plants. Eur. Plan. Stud. 2010, 18, 107-122. [CrossRef]

22. Fallah, M.H.; Choudhury, P. Movement of inventors and the effect of knowledge spillovers on spread of innovation: Evidence from patent analysis in high-tech industries. In Proceedings of the Portland International Center for Management of Engineering and Technology (PICMET 2009), Portland, OR, USA, 2-6 August 2009.

23. Patel, P.; Keith, P. National innovation systems: Why They Are Important, and How they might be measured and compared. Econ. Innov. New Technol. 1994, 3, 77-95. [CrossRef]

24. Wallsten, S.J. The Effects of Government-Industry R\&D Programs on Private R\&D: The Case of the Small Business Innovation Research Program. Rand J. Econ. 2000, 31, 82. [CrossRef]

25. Cowling, M. You can lead a firm to R\&D but can you make it innovate? UK evidence from SMEs. Small Bus. Econ. 2016, 46, 565-577. [CrossRef]

26. Hottenrott, H.; Lopes-Bento, C. (International) R\&D collaboration and SMEs: The effectiveness of targeted public R\&D support schemes. Res. Policy 2014, 43, 1055-1066. [CrossRef]

27. Arrow, K.J. The Economic Implications of Learning by Doing. Rev. Econ. Stud. 1962, 29, 155-173. [CrossRef]

28. Branstetter, L.; Fisman, R.; Foley, C.F.; Saggi, K. Does intellectual property rights reform spur industrial development? J. Int. Econ. 2011, 83, 27-36. [CrossRef]

29. Lee, J.M.; Joo, S.H.; Kim, Y. The complementary effect of intellectual property protection mechanisms on product innovation performance. $R$ D Manag. 2018, 48, 320-330. [CrossRef]

30. Barbu, A.; Militaru, G. The Moderating Effect of Intellectual Property Rights on Relationship between Innovation and Company Performance in Manufacturing Sector. Procedia Manuf. 2019, 32, 1077-1084. [CrossRef]

31. Ang, J.S.; Cheng, Y.; Wu, C. Does Enforcement of Intellectual Property Rights Matter in China? Evidence from Financing and Investment Choices in the High-Tech Industry. Rev. Econ. Stat. 2014, 96, 332-348. [CrossRef]

32. Shi, G.; Pray, C.; Zhang, W. Effectiveness of Intellectual Property Protection: Survey Evidence from China. Agric. Resour. Econ. Rev. 2012, 41, 286-297. [CrossRef]

33. Lee, M.; Alba, J.D.; Park, D. Intellectual property rights, informal economy, and FDI into developing countries. J. Policy Model. 2018, 40, 1067-1081. [CrossRef]

34. Ginarte, J.C.; Park, W.G. Determinants of patent rights: A cross-national study. Res. Policy 1997, 26, $283-301$. [CrossRef]

35. Griliches, Z. Patent Statistics as Economic Indicators: A Survey. J. Econ. Lit. 1990, 28, 1661-1707. [CrossRef]

36. Aristei, D.; Sterlacchini, A.; Venturini, F. Effectiveness of R\&D subsidies during the crisis: Firm-level evidence across EU countries. Econ. Innov. New Technol. 2017, 26, 554-573. [CrossRef]

37. Xu, C.; Shan, X. Constructing of the Index System and Verification for the Intensity of Intellectual Property Protection in China. Stud. Sci. Sci. 2008, 26, 715-723. [CrossRef]

38. Capasso, M.; Treibich, T.; Verspagen, B. The medium-term effect of R\&D on firm growth. Small Bus. Econ. 2015, 45, 39-62. [CrossRef]

39. Yang, C.; Lin, C.; Ma, D. R\&D, Human Capital Investment and Productivity: Firm-level Evidence from China's Electronics Industry. China World Econ. 2010, 18, 72-89. [CrossRef]

40. Bettencourt, L.M.A.; Lobo, J.; Strumsky, D. Invention in the city: Increasing returns to patenting as a scaling function of metropolitan size. Res. Policy 2007, 36, 107-120. [CrossRef]

41. Chevassus-Lozza, E.; Galliano, D. Local Spillovers, Firm Organization and Export Behaviour: Evidence from the French Food Industry. Reg. Stud. 2003, 37, 147-158. [CrossRef]

42. Baron, R.M.; Kenny, D.A. The moderator-mediator variable distinction in social psychological research: Conceptual, strategic, and statistical considerations. J. Pers. Soc. Psychol. 1999, 51, 1173-1182. [CrossRef]

43. Sobel, M.E. Asymptotic Confidence Intervals for Indirect Effects in Structural Equation Models. Sociol. Methodol. 1982, 13, 290-312. [CrossRef] 
44. Edwards, J.R.; Lisa Schurer, L. Methods for integrating moderation and mediation: A general analytical framework using moderated path analysis. Psychol. Methods 2007, 12, 1-22. [CrossRef] [PubMed]

45. Mackinnon, D.P.; Lockwood, C.M.; Hoffman, J.M.; West, S.G.; Sheets, V. A comparison of methods to test mediation and other intervening variable effects. Psychol. Methods 2002, 7, 83-104. [CrossRef] [PubMed]

46. Preacher, K.J.; Rucker, D.D.; Hayes, A.F. Addressing Moderated Mediation Hypotheses: Theory, Methods, and Prescriptions. Multivar. Behav. Res. 2007, 42, 185-227. [CrossRef]

47. Mackinnon, D.P. Introduction to Statistical Mediation Analysis, 1st ed.; Psychology Press: New York, NY, USA, 2008.

48. Hayes, A. Introduction to Mediation, Moderation, and Conditional Process Analysis; The Guilford Press: New York, NY, USA, 2013.

49. Wooldridge, J.M. Econometric Analysis of Cross Section and Panel Data; MIT Press: Cambridge, MA, USA, 2002.

50. Zhang, Q.; Chen, L.; Feng, T. Mediation or Moderation? The Role of R\&D Investment in the Relationship between Corporate Governance and Firm Performance: Empirical Evidence from the Chinese IT Industry. Corp. Gov. Int. Rev. 2014, 22, 501-517. [CrossRef]

51. Han. The Interaction Effect of R\&D Investment and Human Capital Investment on Value Relevance. Korean J. Manag. Account. Res. 2007, 7, 115-136.

52. Lin, J.Y. Effects on diversity of R\&D sources and human capital on industrial performance. Technol. Forecast. Soc. Chang. 2014, 85, 168-184. [CrossRef]

(C) 2020 by the authors. Licensee MDPI, Basel, Switzerland. This article is an open access article distributed under the terms and conditions of the Creative Commons Attribution (CC BY) license (http://creativecommons.org/licenses/by/4.0/). 